\title{
PENGGUNAAN LEVEL SUKROSA TERHADAP SIFAT SENSORIS KEFIR SUSU SAPI
}

\author{
Steviana F.J Rumeen, A. Yelnetty*, M. Tamasoleng, Nova Lontaan \\ Fakultas Peternakan Universitas Sam Ratulangi Manado, 95115
}

\begin{abstract}
ABSTRAK
Penelitian ini bertujuan untuk mengetahui penggunaan level sukrosa terhadap sifat sensoris kefir susu sapi. Bahan yang digunakan adalah susu UHT, grain kefir, skim milk, sukrosa, aquadest, alkohol, spritus. Metode yang digunakan pada penelitian ini adalah Rancangan Acak Lengkap dengan lima perlakuan dan 40 ulangan (panelis). Pengujian sensoris menggunakan skala hedonik. Perlakuan disusun sebagai berikut : $\mathrm{A} 0=$ sukrosa $0 \%$ dan grain kefir $5 \%, \mathrm{~A} 1=$ sukrosa $2 \%$ dan grain kefir $5 \%, \mathrm{~A} 2=$ sukrosa $4 \%$ dan grain kefir $5 \%, \mathrm{~A} 3=$ sukrosa $6 \%$ dan grain kefir $5 \%, \mathrm{~A} 4=$ sukrosa $8 \%$ dan grain kefir $5 \%$. Hasil penelitian ini menunjukkan bahwa perlakuan level sukrosa pada perlakuan $0 \%$, $2 \%, 4 \%, 6 \%, 8 \%$ memberikan pengaruh yang sangat nyata $(\mathrm{P}<0,01)$ terhadap aroma, kekentalan dan cita rasa tetapi tidak berbeda nyata $(\mathrm{P}>0,05)$ terhadap warna. Berdasarkan hasil analisis data pada perlakuan diketahui bahwa penggunaan level sukrosa sebanyak 6\% (A3) merupakan kefir yang lebih disukai berdasarkan pengujian sensoris terhadap warna, aroma, kekentalan dan cita rasa.
\end{abstract}

Kata Kunci : Kefir, Grain Kefir, Sukrosa, Sensoris

\section{ABSTRACT \\ UTILIZATION OF SEVERAL SUCROSE LEVELS ON SENSORY CHARACTERISTICS OF COWS}

*Korespondensi (corresponding author)

Email: afrizayelnetty@yahoo.com
MILK. The present study was conducted to investigate the utilization of several sucrose levels on sensory characteristics of cow milk kefir. Materials used in the study were: UHT milk, grain kefir, skim milk, sucrose, distilled water (aquadest), alcohol, spiritus or methylated spirit. A Completely Randomized Design (CRD) with 5 treatments and 40 replications (panelists) was used in the present study. Treatments were formulated as follow: A0 = sucrose $0 \%$ + grain kefir $5 \%, \mathrm{~A} 1=$ sucrose $2 \%+$ grain kefir 5\%, A2 $=$ sucrose $4 \%+$ grain kefir $5 \%$, $\mathrm{A} 3=$ sucrose $6 \%+$ grain kefir $5 \%$, and $\mathrm{A} 4=$ sucrose $8 \%+$ grain kefir $5 \%$. Sensory test was conducted using hedonic scales. Variables measured were: sensory characteristics consisted of colors, aroma, viscosity, and taste. Tukey test was further employed to analyze treatment differences. Different between treatment(s) was declared at $\mathrm{P}<0.05$. Research results showed that sucrose levels at $0 \%, 2 \%, 4 \%$, $6 \%, 8 \%$ treatments gave a significant effect $(\mathrm{P}<0.01)$ on aroma, viscosity, and taste, but color was not affected $(\mathrm{P}>0.05)$ by treatments. It can be concluded that the utilization of sucrose at the level of $6 \%$ (A3) as most preferred by panelists based on sensory characteristics colors, aroma, viscosity, and taste.

Keywords : Kefir, Grain Kefir, Sucrose, Sensory 


\section{PENDAHULUAN}

Kefir merupakan salah satu pangan fungsional yang dipercaya mengandung nutrisi yang baik serta memiliki khasiat terhadap kesehatan manusia, terutama bagi saluran pencernaan. Bakteri probiotik yang terdapat dalam susu fermentasi kefir telah terbukti secara klinis dapat menyehatkan saluran pencernaan manusia.

Kefir memiliki citra rasa "eksotis" yaitu paduan rasa manis dan sedikit rasa alkohol dan rasa soda seperti rasa tape. Kefir di peroleh melalui proses fermentasi susu pasteurisasi menggunakan stater berupa butir atau biji kefir (kefir grain/kefir granule) yaitu butiran-butiran putih atau krem. Starter biji kefir merupakan biakan starter yang sangat penting dalam pembuatan kefir dan merupakan campuran dari bakteri asam laktat dan khamir (ragi) (Marshall et al., 1984). Penggunaan starter yang berbeda menghasilkan kualitas fermentasi susu yang berbeda dan kualitas susu fermentasi dapat ditingkatkan dengan penambahan sukrosa (Tamime, 2006).

Penggunaan level sukrosa pada saat pembuatan kefir sangat mempengaruhi kualitas dari kefir. Selain kualitas mikrobiologi dan kimiawi pada kefir, sukrosa yang digunakan dapat mempengaruhi cita rasa dan sifat sensoris lainnya. Sukrosa merupakan sumber energi yang dibutuhkan oleh mikroorganisme selama proses fermentasi berlangsung. Banyaknya sukrosa yang dimanfaatkan selama proses fermentasi tergantung pada jenis mikroorganisme yang digunakan. Grain kefir yang digunakan pada penelitian ini mengandung Saccharomyces Kefir, Lactobacillus, Lactococcus Sp dan Streptococcus lactis. Penggunaan mikroorganisme Saccharomyces Kefir, Lactobacillus, Lactococcus Sp dan Streptococcus lactis dengan level sukrosa yang berbeda belum diperoleh penjelasan secara ilmiah.

Berdasarkan hal tersebut diatas maka pada penelitian ini dikaji penggunaan level sukrosa yang berbeda-beda terhadap sifat sensoris kefir susu sapi.

\section{MATERI DAN METODE PENELITIAN}

\section{Materi Penelitian}

Bahan. Bahan yang digunakan adalah 15 liter susu UHT, grain kefir 5\% skim milk 2\%, sukrosa (gula pasir) 480 gram, aquadest, alkohol, spritus, dan bahanbahan untuk pengujian sensoris yang digunakan antara lain air mineral, tusuk gigi dan ketimun.

Alat. Peralatan yang digunakan selama penelitian anatara lain, lemari pendingin, autoclave, incubator, 
timbangan, erlenmeyer, tabung reaksi, $\mathrm{pH}$ meter, waterbath, oven, gelas ukur, saringan, pensil, penghapus, kertas, tusuk gigi, dan cup es krim.

\section{Metode Penelitian Dan Rancangan Percobaan}

Rancangan penelitian yang digunakan pada penelitian ini adalah Rancangan Acak Lengkap (RAL) dengan perlakuan level sukrosa $0 \%, 2 \%, 4 \%, 6 \%$, $8 \%$ dan grain kefir masing-masing perlakuan diulang sebanyak 4 kali

Level starter grain kefir dan gula yang digunakan adalah :

$\mathrm{A} 0=$ sukrosa $0 \%$ dan grain kefir 5\%

$\mathrm{A} 1=$ sukrosa $2 \%$ dan grain kefir $5 \%$

$\mathrm{A} 2=$ sukrosa $4 \%$ dan grain kefir 5\%

$\mathrm{A} 3=$ sukrosa $6 \%$ dan grain kefir $5 \%$

A4 $=$ sukrosa $8 \%$ dan grain kefir $5 \%$

Pembuatan Kefir Susu Sapi (Yelnetty et al., 2016)

1. Perbanyak grain kefir (bibit kefir) dengan menambahkan susu sebagai media pertumbuhan kemudian di fermentasikan disuhu ruang selama 24 jam kemudian disaring kemudian di tambahkan kembali susu.

2. Pasteurisasi susu. susu UHT sebanyak $650 \mathrm{ml}$ masing-masing dimasukkan kedalam wadah dan ditambahkan susu skim $2 \%$ dan sukrosa $0 \%, 2 \%, 4 \%, 6 \%$,
$8 \%$ diaduk kemudian dipasteurisasi di water bath hingga mencapai $80^{\circ} \mathrm{C}$ selama 15 menit, kemudian lakukan pendinginan sampai mencapai suhu ruang $\pm 28^{\circ} \mathrm{C}$. Setelah bahan kefir dingin dilakukan inokulasi dengan penambahan grain kefir masing-masing $5 \%$ kedalam botol kaca steril sesuai dengan perlakuan yang telah ditetapkan.

3. Inkubasi dilakukan pada suhu ruang pada temperatur $\left(28^{\circ} \mathrm{C}\right)$ selama 24 jam. Inkubasi yang dilakukan dimaksudkan untuk memberi waktu kepada mikroba untuk berkembang biak dan meghasilkan hasil metabolit yang akan mempengaruhi rasa dan aroma dari kefir.

4. Penyaringan

Susu yang telah difermentasikan kemudian disaring untuk memisahkan antara biji kefir dengan filtrat yang dihasilkan. Pemisahan ini juga bertujuan supaya fermentasi yang dilakukan oleh kefir tidak berlanjut

5. Pendinginan

Setelah dilakukan penyaringan, filtrat hasil penyaringan didinginkan pada suhu $10^{\circ} \mathrm{C}$ selama $24 \mathrm{jam}$.

Kandungan kimia kefir terdiri dari Total solid, abu, lemak, protein, serat. Untuk lebih jelas dapat dilihat pada pada Tabel 1 . 
Tabel 1. Kandungan kimia kefir

\begin{tabular}{ll}
\hline Komposisi & Persentase \\
\hline Total Solid & $10,18 \pm 0,078$ \\
Abu & $0,92 \pm 0,016$ \\
Lemak & $2,26 \pm 0,025$ \\
Protein & $3,55 \pm 0,156$ \\
Serat & $0,156 \pm 0.006$ \\
\hline
\end{tabular}

Sumber : Yelnetty et al. (2016)

\section{Variabel Pengamatan}

Variabel yang di amati pada penelitian ini adalah sifat sensoris atau organoleptik yang terdiri dari warna, aroma, kekentalan, citarasa dengan skor penilaian $1=$ sangat tidak suka, $2=$ tidak suka, 3= agak tidak suka, 4= biasa/netral, $5=$ agak suka, $6=$ suka, $7=$ sangat suka.

\section{HASIL DAN PEMBAHASAN}

\section{Warna}

Data pada Tabel 2. Menunjukkan bahwa tingkat kesukaan panelis terhadap warna kefir dengan perlakuan level sukrosa yang berbeda, berada pada kisaran dengan rataan 5,18 dengan kriteria (agak suka) sampai 5,83 (sangat suka). Nilai rataan skor tertinggi penerimaan panelis terhadap warna diperoleh pada pengunaan level $6 \%$ dan terendah pada penggunaan level sukrosa $8 \%$.

Berdasarkan hasil pengujian yang telah dilakukan, panelis lebih menyukai warna kefir dengan perlakuan level 6\% dengan skor 5,83 yang termasuk dalam kategori suka. Berdasarkan hasil analisis sidik ragam menujukkan bahwa perlakuaan level sukrosa yang berbeda tidak memberikan pengaruh yang nyata $(\mathrm{P}>0,05)$ terhadap tingkat kesukaan warna kefir yang dihasilkan. Hal ini kemungkinan disebabkan karena warna pada kefir dengan perlakuan level sukrosa yang berbeda tidak mempengaruhi terjadinya perubahan warna terhadap kefir yang dihasilkan, warna yang dihasilkan hampir sama semua yaitu putih krem sehingga banyak panelis yang menyukai. Menurut Aristya et al. (2013), warna merupakan salah satu parameter yang digunakan untuk menilai suatu produk pangan dan dapat menunjang kualitasnya. Bahan pangan yang memiliki warna menarik akan menimbulkan kesan positif, walaupun belum tentu rasanya enak.

\section{Aroma}

Data pada Tabel 2. Menunjukkan bahwa tingkat kesukaan panelis terhadap aroma kefir dengan perlakuan level sukrosa yang berbeda, berada pada kisaran dengan rataan 4,98 dengan kriteria (agak suka) sampai 5.58 (suka). Nilai rataan skor tertinggi penerimaan panelis terhadap aroma diperoleh pada penggunaan level $6 \%$ dan terendah pada level $8 \%$.

Berdasarkan hasil pengujian yang telah dilakukan panelis lebih menyukai aroma kefir dengan perlakuan level 6\% 
Tabel 2. Rataan Pengaruh Perlakuan Terhadap Sifat Sensoris Kefir

\begin{tabular}{llllll}
\hline \multirow{2}{*}{ Variabel } & \multicolumn{5}{c}{ Perlakuan } \\
\cline { 2 - 6 } & A0 & A1 & A2 & A3 & A4 \\
\hline Warna & 5,30 & 5,33 & 5,28 & 5,83 & 5,18 \\
Aroma & $4,98^{\mathrm{a}}$ & $5,03^{\mathrm{a}}$ & $5,40^{\mathrm{ab}}$ & $5,58^{\mathrm{ab}}$ & $4,88^{\mathrm{a}}$ \\
Kekentalan & $4,98^{\mathrm{a}}$ & $4,93^{\mathrm{a}}$ & $4,83^{\mathrm{a}}$ & $5,55^{\mathrm{b}}$ & $4,78^{\mathrm{a}}$ \\
Cita rasa & $4,75^{\mathrm{b}}$ & $5,20^{\mathrm{a}}$ & $5,15^{\mathrm{a}}$ & $5,65^{\mathrm{b}}$ & $4,98^{\mathrm{a}}$ \\
\hline
\end{tabular}

Keterangan: Superskrip yang berbeda pada baris yang sama artinya berbeda sangat nyata $(\mathrm{P}<0,01)$

dengan skor 5.58 yang termasuk dalam kategori suka. Berdasarkan hasil analisis sidik ragam menunjukkan bahwa perlakuan level sukrosa $0 \%, 2 \%, 4 \%, 6 \%, 8 \%$ memberikan pengaruh yang berbeda nyata $(\mathrm{P}<0.05)$ terhadap aroma kefir yang dihasilkan.

Berdasarkan hasil uji lanjut dengan Uji Beda Nyata Jujur menunjukkan bahwa perlakuan A0 tidak berbeda nyata $(\mathrm{P}>0.05)$ terhadap A1, A2, A4 tetapi A0 berbeda nyata $(\mathrm{P}<0.05)$ terhadap A3. Perlakuan A1 tidak berbeda nyata terhadap A0, A2, A4 tetapi A1 berbeda nyata $(\mathrm{P}<0.05)$ terhadap A3. Perlakuan A2 tidak berbeda nyata $(\mathrm{P}>0.05)$ terhadap A0, A1, A3, A4. Perlakuan A3 berbeda nyata terhadap $(\mathrm{P}<0.05)$ A0, A1, A4 tetapi A3 tidak berbeda nyata $(\mathrm{P}>0.05)$ terhadap A2. Perlakuan A4 tidak berbeda nyata $(\mathrm{P}>0.05)$ terhadap A0, A1, A2 tetapi A4 berbeda nyata $(\mathrm{P}<0.05)$ terhadap A3. Hal ini di sebabkan karena penambahan sukrosa berpengaruh terhadap aroma yang dihasilkan. Usmiati (2007), Menyatakan kefir merupakan susu fermentasi yang memiliki rasa, warna dan konsistensi yang menyerupai yogurt dan memiliki aroma khas (seperti tape), sehingga semakin banyak penambahan sukrosa, aroma yang terbentukpun semakin kuat. Aroma yang menyerupai tape disebabkan karena adanya alkohol dan ester yang tinggi. Menurut Hui (1993) Sukrosa (gula) berpengaruh sebagai sumber energi pertumbuhan bakteri asam laktat. Lactobacillus bulgaricus berperan dalam menghasilkan asam laktat sedangkan Streptococus lactis lebih berperan dalam pembetukan aroma dan flavor (cita rasa). Ditambahkan oleh (Hartatie 2011), bahwa aroma pada produk fermentasi yang dihasilkan sangat dipengaruhi oleh bahanbahan yang digunakan dalam pembuatan produk tersebut.

\section{Kekentalan}

Data pada Tabel 2. Menunjukkan bahwa tingkat kesukaan panelis terhadap kekentalan kefir dengan perlakuan level sukrosa yang berbeda, berada pada kisaran 
dengan rataan 4,78 dengan kriteria (agak suka) sampai 5,55 (suka). Nilai rataan skor tertinggi penerimaan panelis terhadap kekentalan diperoleh pada penggunaan level $6 \%$ dan terendah pada level $8 \%$.

Berdasarkan hasil pengujian yang telah dilakukan panelis lebih menyukai kekentalan kefir dengan perlakuan level $6 \%$ dengan skor 5,55 yang termasuk dalam kategori suka. Berdasarkan hasil analisis sidik ragam menujukkan bahwa perlakuan dengan level sukrosa 0\%, 2\%, 4\%, 6\%, $8 \%$ memberikan pengaruh yang berbeda nyata $(\mathrm{P}<0,05)$ terhadap kekentalan kefir yang dihasilkan.

Berdasarkan hasil uji lanjut dengan Uji Beda Nyata Jujur menunjukkan bahwa perlakuan A0 tidak berbeda nyata $(\mathrm{P}>0,05)$ terhadap A1, A2, dan A4 tetapi A0 berbeda nyata $(\mathrm{P}<0.05)$ terhadap A3. Perlakuan A1 tidak berbeda nyata $(\mathrm{P}>0,05)$ terhadap $\mathrm{A} 0$, A2, A4 tetapi A1 berbeda nyata $(\mathrm{P}<0,05)$ terhdap A3. Perlakuan A2 tidak berbeda nyata $(\mathrm{P}>0,05)$ terhadap $\mathrm{A} 0, \mathrm{~A} 1, \mathrm{~A} 4$ tetapi A2 berbeda nyata $(\mathrm{P}<0,05)$ terhadap A3. Perlakuan A3 berbeda nyata $(\mathrm{P}<0,05)$ terhadap A0, A1, A2, A4. Perlakuan A4 tidak berbeda nyata $(\mathrm{P}>0,05)$ terhadap $\mathrm{A} 0$, A1, A2 tetapi A4 berbeda nyata $(\mathrm{P}<0,05)$ terhadap A3. Kekentalan atau viskositas kefir atau susu fermentasi lainnya disebabkan karena proses koagulasi susu akibat dari aktivitas mikroba dalam starter karena ada pemanfaatan laktosa dan kasein yang menyebabkan terjadinya kekentalan. Menurut Tamime dan Deeth (1980), Kekentalan yang terbentuk pada produk susu fermentasi dapat disebabkan oleh penggumpalan protein oleh asam yang dihasilkan selama proses fermentasi. Salah satu faktor yang mempengaruhi kekentalan kefir adalah kadar asam laktat yang dapat menggumpalkan protein dalam susu. Pembentukan asam laktat sangat penting dalam pembuatan susu fermentasi, selain sebagai pendukung cita rasa juga membantu destabilisasi protein. Destabilisasi protein akan menyebabkan terjadinya penggumpalan, sehingga produk susu fermentasi menjadi kental. Penggunaan sukrosa sampai level 6\% merupakan kefir yang peling disukai sifat kekentalannya oleh panelis.

\section{Cita rasa}

Data pada Tabel 2. Menunjukkan bahwa tingkat kesukaan panelis terhadap cita rasa kefir dengan perlakuan level sukrosa yang berbeda, berada pada kisaran dengan rataan 4,98 dengan kriteria (agak suka) sampai 5,75 (sangat suka). Nilai rataan skor tertinggi penerimaan panelis terhadap cita rasa diperoleh pada penggunaan level $6 \%$ dan terendah pada penggunaan level sukrosa $0 \%$.

Berdasarkan hasil pengujian yang telah dilakukan panelis lebih menyukai cita rasa kefir dengan perlakuan level $6 \%$ 
dengan skor 5,75 yang termasuk dalam kategori suka. Berdasarkan hasil analisis sidik ragam menunjukkan bahwa perlakuan level sukrosa 0\%, 2\%, 4\%, 6\%, $8 \%$ memberikan pengaruh berbeda sangat nyata $(\mathrm{P}<0,01)$ terhadap cita rasa kefir.

Berdasarkan hasil uji lanjut Uji Beda Nyata Jujur menunjukkan bahwa perlakuan A0 berbeda sangat nyata $(\mathrm{P}<0,01)$ terhadap A1, A2, A4 tetapi A0 tidak berbeda nyata $(\mathrm{P}>0,05)$ terhadap A3. Perlakuan A1 tidak berbeda nyata $(\mathrm{P}>0,05)$ terhadap A2, A4 tetapi A1 berbeda sangat nyata $(\mathrm{P}<0,01)$ terhadap A0 dan A3. Perlakuan A2 tidak berbeda nyata $(\mathrm{P}>0,05)$ terhadap A1, A4 tetapi A2 berbeda sangat nyata $(\mathrm{P}<0,01)$ terhadap A0 dan A3. Perlakuan A3 berbeda sangat nyata $(\mathrm{P}<0,01)$ terhadap A4, A2, A1 tetapi A3 tidak berbeda nyata $(\mathrm{P}>0,05)$ terhadap $\mathrm{A} 0$. Perlakuan A4 tidak berbeda nyata $(\mathrm{P}>0,05)$ terhadap A1, A2 tetapi A4 berbeda sangat nyata $(\mathrm{P}<0,01)$ terhadap A0, dan A3. Dari data di atas dapat disimpulkan bahwa panelis lebih menyukai kefir dengan perlakuan A3 dengan penambahan sukrosa 6\%. Menurut Agustina et al. (2013) menunjukkan bahwa tingkat penerimaan panelis secara keseluruhan pada produk fermentasi dengan starter BAL sangat dipengaruhi oleh tingkat keasaman produk, dimana tingkat keasaman yang semakin meningkat akan semakin menurunkan tingkat penerimaan panelis. Sesuai dengan penelitian Bills et al. (1972) bahwa penambahan sukrosa pada level sukrosa $8 \%$ atau lebih tinggi berpengaruh pada produksi asam laktat sebagai penghasil cita rasa.

Rasa asam kefir susu sapi sangat kuat, dikarenakan dalam kefir telah terjadi perombakan laktosa menjadi asam laktat. Keasaman yang tinggi disebabkan besarnya kandungan asam laktat yang ada, bakteri asam laktat menghasilkan enzim $\beta$ galaktosidase yang akan mengubah laktosa menjadi asam laktat. Rasa pada minuman kefir disebabkan karena bakteri akan menghasilkan komponen flavor, ragi akan menghasilkan karbondioksida dan alkohol. Itulah sebabnya rasa kefir asam dan terdapat rasa alkohol serta soda dan kombinasi alkohol dan karbondioksida menghasilkan buih (Yusriah dan Agustini, 2014)

Berdasarkan skala tingkat kesukaan diketahui bahwa panelis menerima semua level sukrosa yang ditambahkan pada kefir. Nilai skor yang paling disukai pada perlakuan A3 yakni 6\% sukrosa. 


\section{KESIMPULAN}

Berdasarkan hasil penelitian dapat disimpulkan bahwa kefir dengan penggunaan level sukrosa $6 \%$ merupakan kefir yang paling disukai oleh panelis.

\section{DAFTAR PUSTAKA}

Agustina, L., T. Setyawardani, dan T.Y. Astuti. 2013. Penggunaan starter biji kefir dengan konsentrasi yang berbeda pada susu sapi terhadap $\mathrm{pH}$ dan kadar asam laktat. Jurnal Ilmiah Peternakan 1 (1): 254-259.

Aristya, A. L., A.M. Legowo, dan A.N. AlBaarri. 2013. Karakteristik fisik, kimia, dan mikrobiologis kefir susu kambing dengan penambahan jenis dan konsentrasi gula yang berbeda. Jurnal Aplikasi Teknologi Pangan 2(3): 139-143.

Bills, D, C.S. Yang, M.E. Morgan, and F.W. Bodyfelt. 1972 Effect of sucrose on the production of acetaldehyde and acids by yogurt culture bacteria. Journal of Dairy Science 55: 1570-1573.

Hartatie, E.S. 2011. Kajian formulasi (bahan baku, bahan pemantap) dan metode pembuatan terhadap kualitas es krim. GAMMA, Vol 7(1): $20-26$
Hui, Y. H. 1993. Dairy Science and Technology Handbooks: Principles and Properties.

Marshall, V. M., W.M. Cole, and J. A. Farrow. 1984. A note on the heterofermentative Lactobacillus isolated from kefir grains. Journal Applied Bacteriology 56(3): 503505

Tamime, A. Y. dan H.C. Deeth. 1980. Yoghurt: Technology and Biochemistry. Journal of Food Protect. 43 (12): 939-977.

Tamime, A. Y. 2006. Production of Kefir, Koumis and Other Related Products. In: A.Y. Tamime (ed.), Fermented Milk. Blackwell Science Ltd, Oxford.

Usmiati, S. 2007. Kefir, Susu Fermentasi dengan Rasa Menyegarkan. Warta Penelitian dan Pengembangan Pascapanen Pertanian Vol. 29 (2): 12-14

Yelnetty, A., R. Hadju, A. D. Mirah. Pengembagan Pangan Fungsional Kefir Symbiotik Menggunakan Kolang Kaling Sebagai Sumber Probiotik. Laporan Penelitian. 2016 Laporan Penelitian. Fakultas Peternakan Universitas Sam Ratulangi

Yusriah, N. H. dan R. Agustini. 2014. Pengaruh waktu fermentasi dan konsentrasi bibit kefir terhadap mutu kefir susu sapi. UNESA Jurnal of Chemistry 3(2): 53-57 